\title{
KONDISI TERUMBU KARANG DI KAWASAN SUAKA ALAM PERAIRAN SELAT PANTAR DAN LAUT SEKITARNYA DI KABUPATEN ALOR
}

\author{
Conditions of Coral Reefs in the Aquatic Reserve of Pantar Strait, Alor Regency
}

\author{
Oleh \\ Imanuel Lamma Wabang \\ Staf Pengajar Fakultas Pertanian dan Perikanan Universitas Tribuana Kalabahi, Kabupaten \\ Alor, Nusa Tenggara Timur \\ Korespondensi: wabangimanuel18@gmail.com
}

\begin{abstract}
ABSTRAK
Penelitian bertujuan untuk mengetahui kondisi terumbu karang meliputi tutupan karang, bentuk pertumbuhan karang dan indeks kematian karang di Kawasan Suaka Alam Perairan Selat Pantar. Penelitian ini telah dilaksanakan pada bulan Juni sampai Agustus 2018. Stasiun penelitian dibagi ke dalam 14 stasiun yang didasarkan pada karakteristik lingkungan. Pengambilan data terumbu karang menggunakan metode Line Intercept Transect (LIT). Hasil penelitian menunjukkan bahwa tutupan terumbu karang pada lokasi penelitian berkisar antara $27.71 \%$ hingga $79.22 \%$ dan tergolong kategori kondisi sedang hingga sangat baik. Tutupan terumbu karang yang rendah disebabkan oleh lokasi ini sering terjadi penangkapan ikan menggunakan alat tangkap yang tidak ramah lingkungan seperti bubu dan bahan peledak. Tutupan karang yang tertinggi di lokasi perairan ini diduga adanya pengawasan di sekitar kawasan yang dilakukan oleh pemilik home stay dan masyarakat setempat sehingga membuat lokasi ini aman dari kegiatan penangkapan yang tidak ramah lingkungan. Nilai indeks kematian karang berkisar 0,01 - 0,47, namun rata-rata keseluruhan nilai indeks kematian karang sebesar 0,16, menunjukkan perubahan kondisi dari karang hidup menjadi karang mati belum terlalu berarti.
\end{abstract}

Kata kunci : LIT, SAP Selat Pantar, Terumbu Karang

\begin{abstract}
The study aimed to determine the condition of coral reefs including coral cover in the form of coral growth and coral mortality index in the Pantar Strait Watershed Area. This research was carried out from June to August 2018. The research station was divided into 14 stations based on environmental characteristics. Collecting coral reef data using the Line Intercept Transect (LIT) method. The results showed that coral cover in the study area ranged from $27.71 \%$ to $79.22 \%$ and classified as moderate to very good conditions. Low coral reef cover is caused by this location where fishing often occurs using non-environmentally friendly fishing gear such as traps and explosives. The highest coral cover in these water locations is suspected of being monitored around the area by home stay owners and local communities, making this location safe from fishing activities that are not environmentally friendly. Coral mortality index values ranged from $0.01-0.47$, but the average overall coral mortality index value was 0.16 , indicating changes in the condition of living corals into dead corals were not too significant.
\end{abstract}

Keywords : LIT, Pantar Strait Watershed Area, Coral Reef 


\section{PENDAHULUAN}

Ekosistem terumbu karang merupakan bagian dari ekosistem laut yang menjadi sumber kehidupan bagi beraneka ragam biota laut. Di dalam ekosistem terumbu karang bisa hidup lebih dari 400 jenis karang, lebih dari 200 jenis ikan dan berpuluh-puluh jenis moluska, crustacea, sponge, algae, lamun dan biota laut lainnya (Moosa et al., 1996 dalam Suharsono, 1996).

Ekosistem terumbu karang merupakan ekosistem laut yang menjadi sumber kehidupan bagi beraneka ragam biota laut sehingga keberadaannya sangat penting. Menurut Sukmara et al. (2001) Terumbu karang memiliki manfaat ekologi dan manfaat ekonomi karena keberadaan biota yang hidup di dalamnya. Manfaat ekologi terumbu karang antara lain sebagai habitat hidup, tempat berkembang, mencari makan, serta tempat memijah berbagai biota laut. Manfaat ekonomi terumbu karang yaitu sebagai tempat menangkap biota laut untuk konsumsi serta berbagai jenis ikan hias, perhiasan atau kerajinan tangan, bahan baku farmasi, dan sebagai kawasan wisata atau rekreasi.

Kawasan Konservasi Perairan Daerah (KKPD) Kabupaten Alor telah dideklarasikan untuk perluasannya seluas 400.000,083 ha, dan telah dilegitimasi melalui Peraturan Bupati Nomor 6 Tahun 2009. Pencadangan KKPD Kabupaten Alor adalah momentum dari Pemerintah Kabupaten Alor sebagai langkah awal untuk pengelolaan perairan laut dan pesisir yang lebih baik dan lebih mensejahterahkan masyarakat pesisir Kabupaten Alor. Tindak lanjut pencadangan KKPD tersebut adalah Pada tahun 2015 telah disahkan melalui SK Menteri Kelautan dan Perikanan Nomor 3/KEPMEN-KP/2015 Tentang Kawasan Konservasi Perairan Selat Alor Pantar dan Laut Sekitarnya di Kabupaten Alor Propinsi Nusa Tenggara Timur dengan status Suaka Alam Perairan.

Kawasan Suaka Alam Perairan Selat Pantar dan laut sekitarnya memiliki sebaran terumbu karang dengan luas 3.329.94 Ha, yang tersebar di beberapa pulau kecil yang ada di daerah ini. Kawasan ini memiliki 75 spesies karang keras dari 31 genus famili karang. Secara umum kondisi terumbu karang di kawasan ini termasuk dalam kategori sedang dengan tutupan karang hidup sebesar 34.95\% (DKP Kab. Alor, 2013).

Hasil laporan pemantauan kondisi terumbu karang menggunakan metode Reef Health pada periode tahun 2011 menunjukkan bahwa kondisi tutupan karang keras KKPD Kabupaten Alor di Zona Pemanfaatan lebih tinggi dibandingkan Zona Larang Ambil. Sehingga dalam pengelolaannya lokasi yang diusulkan menjadi Zona Larang Ambil tersebut harus mendapatkan perhatian lebih mengingat kondisinya tidak lebih baik dari Zona Pemanfaatan. Calon Zona Larang Ambil sekiranya mempunyai sumberdaya untuk dapat mensuplai Zona Pemanfaatan. Kondisi perikanan di KKPD Kabupaten Alor juga menunjukkan tanda-tanda penangkapan berlebih dimana sedikitnya kelimpahan ikan berukuran besar $(>30 \mathrm{~cm})$.

Tujuan penelitian ini adalah untuk mengetahui kondisi terkini terumbu karang yang di Kawasan Suaka Alam Perairan Selat Pantar, Kabupaten Alor. data kondisi tersebut sangat dibutuhkan untuk mengetahui kecenderungan yang terjadi pada ekosistem terumbu karang sehingga dapat dirumuskan satu bentuk pengelolaan yang terbaik untuk menjaga kelestariannya.

\section{METODE PENELITIAN}

Penelitian ini dilaksanakan di Kawasan Suaka Alam Perairan Selat Pantar Kabupaten Alor Propinsi Nusa Tenggara Timur pada bulan Juni s/d Agustus 2018. Penentuan stasiun penelitian dilakukan dengan purposive sampling. Jumlah stasiun dalam penelitian ini sebanyak 14 titik (Gambar 1) 

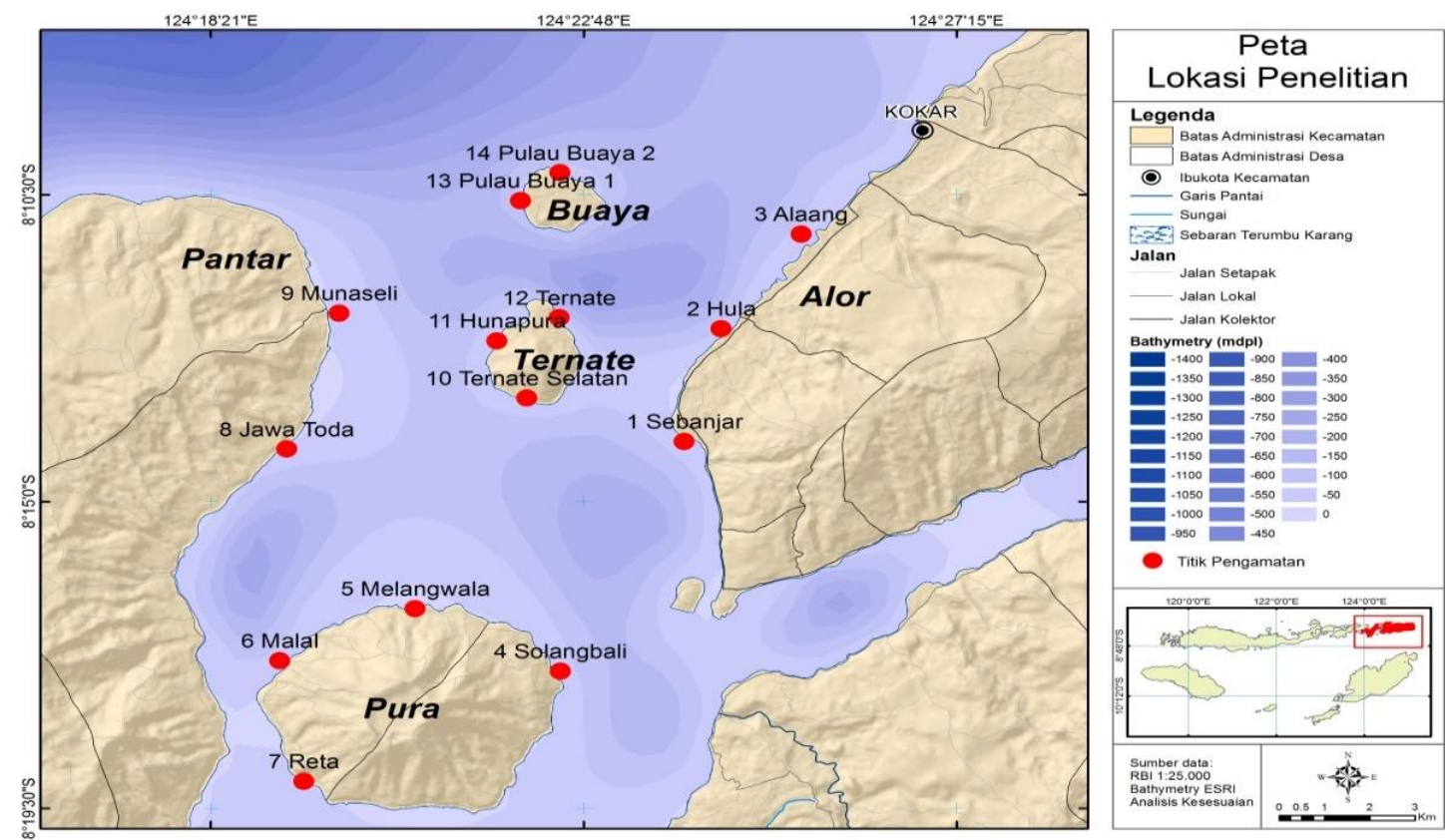

Gambar 1. Peta Lokasi Penelitian

Pengambilan data dilakukan dengan petunjuk English et al. (1997), dimana ukuran transek sepanjang $50 \mathrm{~m}$ mengikuti arah garis pantai. Lokasi pengambilan data ditetapkan setelah melihat hasil yang diperoleh melalui teknik manta-tow, dimana pada setiap lokasi ditentukan 1 titik untuk dijadikan lokasi peletakan transek dengan teknik Line Intercept Transect (LIT). Setiap lifeform karang yang dilewati transek dicatat dan difoto yang selanjutnya akan diidentifikasi menurut kondisi dan taksonnya dengan menggunakan buku identifikasi menurut (Suharsono 2008). Dari data tersebut akan diketahui persentase tutupan karang, dominasi lifeform, jumlah jenis lifeform dan kategori karang mati dan karang hidup.

Alat dan bahan yang digunakan dalam penelitian ini: 1) alat selam SCUBA, 2) roll meter, 3) sabak dan pensil, 4) kamera bawah air 5) GPS, dan 6) perahu/boat.

Analisis yang digunakan untuk menentukan parsen tutupan komunitas karang adalah menggunakan metode Line Intercept Transect (LIT) mengikuti persamaan English et al. (1997). Data presentasi penutupan terumbu karang diperoleh dari hasil pengukuran lifeform (intercept koloni) karang dengan menggunakan rumus :

$$
N i=\frac{L i}{L} x 100 \%
$$

Dengan :

$$
\begin{array}{ll}
\mathrm{Ni} & =\text { Persen penutupan karang (\%) } \\
\mathrm{Li} & =\text { Panjang lifeform (intercept koloni) jenis kategori ke-i } \\
\mathrm{L} & =\text { Panjang total transek }(\mathrm{m})
\end{array}
$$

Dari hasil perhitungan diatas akan dianalisis dengan menggunakan kategori parsen tutupan karang dimana parsen tutupan komunitas karang merupakan penjumlahan dari persentase tutupan karang keras, persentase tutupan karang lunak, dan tutupan kategori others (OT) (Yulianda, 2007). Kriteria tersebut menggunakan 4 kategori, yaitu :

1. Kategori Rusak : $0-24,9 \%$

2. Kategori Sedang/Kritis : $: 25-50 \%$

3. Kategori Baik : $: 50,1-75 \%$

4. Kategori Sangat Baik : : $75,1-100 \%$ 
Penilaian suatu kondisi kesehatan terumbu karang tidak hanya berpatokan pada presentase tutupan karang hidup, tapi juga karang mati. Indeks mortalitas (MI/ mortality index) merupakan nilai yang digunakan untuk menggambarkan tingkat kematian di ekosistem terumbu karang. Dihitung menggunakan rumus (English et al.1997)

$$
I M=\frac{\% \text { tutupan karang mati }}{\% \text { karang mati }+\% \text { karang hidup }}
$$

Dengan kisaran IM antara 0-1, maka penjelasannya sebagai berikut:

- Semakin mendekati 0 nilai MI maka semakin kecil tingkat kematiannya dan kesehatan karang semakin baik, dan;

- Semakin mendekati 1 MI maka tingkat kematian semakin besar dan kesehatan karang semakin buruk.

\section{HASIL DAN PEMBAHASAN}

Parameter fisik perairan yang diamati adalah parameter perairan yang mempengaruhi berkembangnya terumbu karang seperti suhu, salinitas, kecerahan dan arus. Menurut Suharsono (2008) pertumbuhan, penutupan dan kecepatan tumbu karang sangat dipengaruhi oleh faktor fisik lingkungan perairan. Pengukuran parameter ini dilakukan bersamaan dengan pengamatan terumbu karang. Hasil pengukuran parameter fisik perairan disajikan pada Tabel 1.

Tabel 1. Kondisi fisik perairan di setiap stasiun penelitian

\begin{tabular}{|c|c|c|c|c|c|}
\hline \multirow[b]{2}{*}{ Stasiun } & \multirow[b]{2}{*}{$\begin{array}{l}\text { Nama Lokasi } \\
\text { Pengamatan }\end{array}$} & \multicolumn{4}{|c|}{ Parameter } \\
\hline & & $\begin{array}{c}\text { Suhu } \\
\left({ }^{\circ} \mathrm{C}\right)\end{array}$ & $\begin{array}{c}\text { Salinitas } \\
(\% 0)\end{array}$ & $\begin{array}{c}\text { Kecerahan } \\
(\%)\end{array}$ & $\begin{array}{l}\text { Arus } \\
(\mathrm{m} / \mathrm{s})\end{array}$ \\
\hline 1 & Sebanjar & $30.31 \pm 0.58$ & $33.00 \pm 0.00$ & $100 \pm 0.00$ & $7.13 \pm 1.53$ \\
\hline 2 & Hula & $30.00 \pm 1.00$ & $32.00 \pm 1.00$ & $98 \pm 2.89$ & $8.00 \pm 0.61$ \\
\hline 3 & Alaang & $30.00 \pm 0.00$ & $32.67 \pm 0.58$ & $100 \pm 0.00$ & $6.07 \pm 1.00$ \\
\hline 4 & Solangbali & $32.10 \pm 0.58$ & $31.31 \pm 0.58$ & $100 \pm 0.00$ & $12.12 \pm 1.15$ \\
\hline 5 & Melangwala & $31.00 \pm 0.00$ & $33.00 \pm 0.00$ & $100 \pm 0.00$ & $10.54 \pm 0.58$ \\
\hline 6 & Malal & $30.00_{ \pm} 0.00$ & $32.00 \pm 1.78$ & $100 \pm 0.00$ & $15.40 \pm 1.00$ \\
\hline 7 & Reta & $31.67 \pm 0.58$ & $31.00 \pm 1.00$ & $88_{ \pm} 1.15$ & $16.10 \pm 2.00$ \\
\hline 8 & Jawa Toda & $30.67 \pm 1.15$ & $32.00 \pm 0.00$ & $95 \pm 0.00$ & $5.20 \pm 0.00$ \\
\hline 9 & Munaseli & $31.00 \pm 0.00$ & $31.67 \pm 1.53$ & $100 \pm 0.00$ & $6.64 \pm 0.58$ \\
\hline 10 & Ternate & $31.00 \pm 1.00$ & $33.00 \pm 0.00$ & $95 \pm 0.00$ & $6.51 \pm 2.08$ \\
\hline 11 & Humapura & $30.00 \pm 1.00$ & $31.33 \pm 2.08$ & $95 \pm 0.00$ & $7.97 \pm 1.15$ \\
\hline 12 & Ternate Selatan & $29.00_{ \pm} 0.00$ & $30.00 \pm 0.00$ & $100 \pm 0.00$ & $9.56 \pm 0.58$ \\
\hline 13 & Buaya 1 & $31.00 \pm 0.00$ & $32.33 \pm 1.15$ & $100 \pm 0.00$ & $9.21 \pm 0.00$ \\
\hline 14 & Buaya 2 & $31.00 \pm 1.00$ & $31.00 \pm 0.00$ & $100 \pm 0.00$ & $11.70 \pm 1.53$ \\
\hline
\end{tabular}

Sumber : Hasil olahan 2018

Hasil pengukuran kondisi tutupan terumbu karang di beberapa stasiun penelitan yang terletak pada lokasi penelitian dengan menggunakan Line Intersept Transect (LIT) dapat di lihat pada Tabel 2.

Berdasarkan hasil penelitian, dari 4 kategori kondisi terumbu karang ditemukan 3 kategori yang terdapat di lokasi penelitian, yakni kondisi sedang, baik dan sangat baik dengan nilai presentase tutupan komunitas karang di lokasi penelitian berkisar dari $27,71 \%-79,22 \%$. 
Tabel 2. Kondisi terumbu karang disetiap stasiun penelitian

\begin{tabular}{cllllll}
\hline Stasiun & Lokasi & LC & DC & OT & AB & Kondisi \\
\hline 1 & Sebanjar & 47,19 & 27,48 & 12,36 & 19,97 & Sedang \\
2 & Hula & 51,67 & 12,32 & 11,59 & 18,53 & Baik \\
3 & Alaang & 62,56 & 15,48 & 7,61 & 14,03 & Baik \\
4 & Solangbali & 43,45 & 26,43 & 11,59 & 18,53 & Sedang \\
5 & Melangwala & 56,55 & 8,067 & 9,06 & 25,73 & Baik \\
6 & Malal & 34,32 & 20,31 & 13,36 & 32,01 & Sedang \\
7 & Reta & 27,71 & 24,68 & 15,02 & 32,41 & Sedang \\
8 & Jawa Toda & 69,26 & 7,14 & 11,76 & 10,09 & Baik \\
9 & Munaseli & 58,48 & 14,71 & 6,73 & 0,84 & Baik \\
10 & Ternate & 64,22 & 11,87 & 14,9 & 8,97 & Baik \\
11 & Humapura & 63,91 & 7,12 & 22,17 & 6,08 & Baik \\
12 & Ternate Selatan & 79,22 & 1,09 & 7,44 & 12,35 & Sangat Baik \\
13 & Buaya 1 & 76,10 & 4,98 & 9,27 & 09,65 & Sangat Baik \\
14 & Buaya 2 & 63,27 & 6,11 & 13,09 & 15,21 & Baik \\
\hline
\end{tabular}

Keterangan : LC : Life Coral, DC :Death Coral, OT : Other Fauna, AB : Abiotik

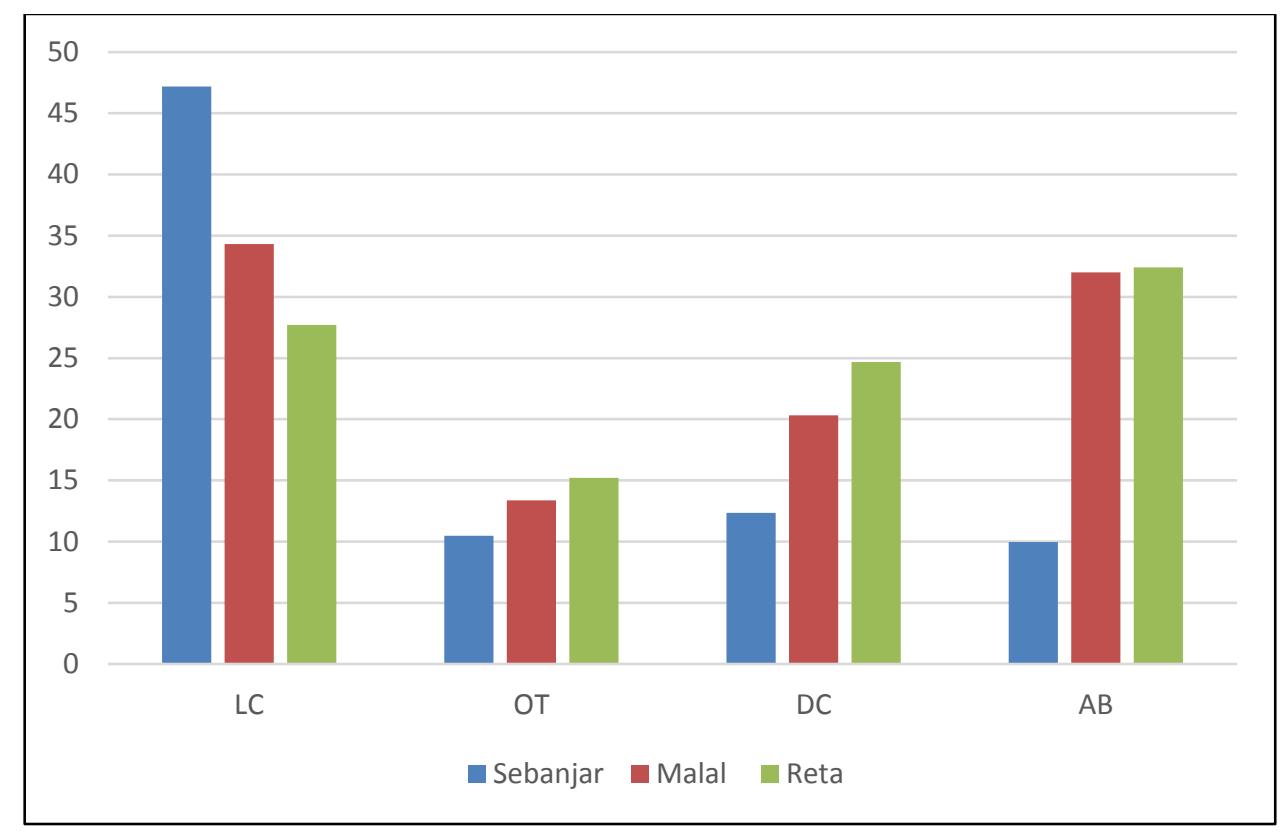

Gambar 2. Presentase dan sebaran terumbu karang kondisi sedang

Kondisi sedang terdapat di 3 stasiun (Gambar 2) yakni terdapat pada lokasi Sebanjar, Malal dan Reta yang terletak stasiun 1, 6 dan 7, dengan nilai kisaran 27,71\% - 47,19\%. Nilai tutupan terendah berada di stasiun 7 (Reta) dengan nilai kisaran 27,71\%, yang tediri dari 10,71\% karang bercabang (Acropora) dan karang keras lainnya (Non-Acropora) sebesar 17,0\% dengan bentuk pertumbuhan karang yakni Acropora Branching dan Branching. Sedangkan tutupan karang tertinggi di stasiun 1 yakni Sebanjar dengan nilai persentase sebesar 47,19\% dengan bentuk pertumbuhan Branching dan Acropora Tabulate. Tutupan karang mati tertinggi di stasiun Reta dan terendah di stasiun Sebanjar. Hal ini mengindikasikan bahwa lokasi ini sering terjadi penangkapan ikan menggunakan alat tangkap yang tidak ramah lingkungan seperti bubu dan bahan peledak, hal ini sesuai dengan yang dikemukakan Hartoni et al. (2012), bahwa praktek penangkapan ikan dengan pengeboman adalah penyebab utama degradasi terumbu karang. Patahan karang yang dihasilkan oleh aktivitas penangkapan ikan tersebut tidak dapat bertahan hidup dan dapat mengambat pertumbuhan karang baru. 


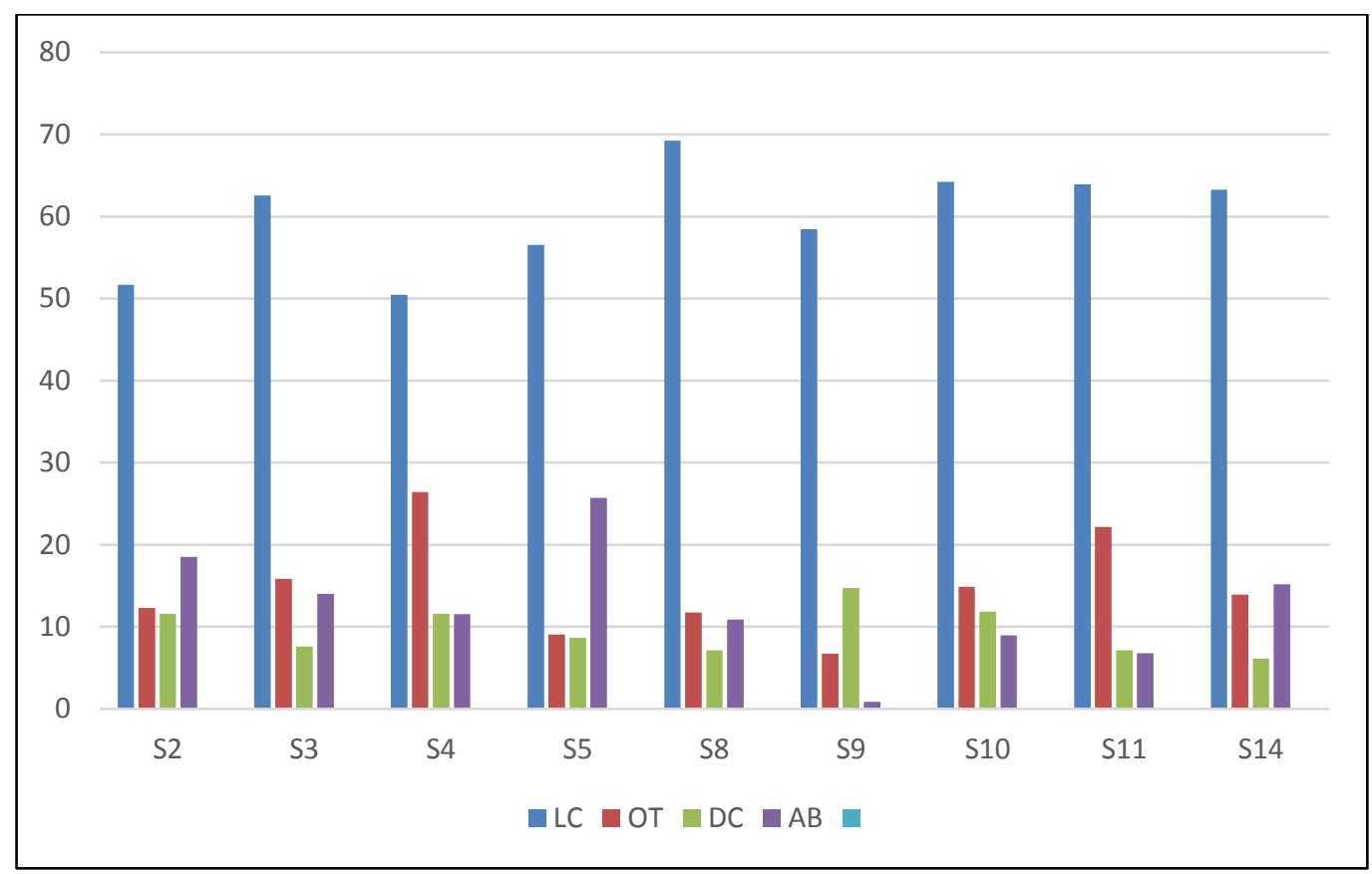

Gambar 3. Presentase dan sebaran terumbu karang kondisi baik

Tutupan karang dengan kondisi baik ditemukan di sembilan stasiun yakni Hula, Alaang, Solangbali, Melangwala, Jawa Toda, Munaseli, Ternate, Ternate Selatan, Humapura dan Buaya 2 dengan nilai kisaran $51,67 \%-69,26 \%$. Nilai tutupan terendah terdapat di stasiun Hula yang terdiri dari $21 \%$ karang bercabang (Acroporsa sp) dan 29,67\% karang keras lainnya (Non-Acropora). Berdasarkan bentuk pertumbuhan terumbu karang, hasil penelitian menujukan pertumbuhnya (lifeform) di kawasan suaka alam perairan Selat Pantar ditemukan jumlah lifeform setiap kawasan penelitian bervariasi. Sedangkan kategori karang keras (hard coral) terdiri dari Acropora dan Non-Acropora. Bentuk pertumbuhan terumbu karang adalah acropora massif dan sub massive. Sedangkan nilai tutpan terumbu karang tertinggi ditemukan di stasiun 8 (Jawa Toda) dengan nilai kisaran 69,26\% yang didominasi oleh jenis karang bercabang (Acropora $s p$ ).

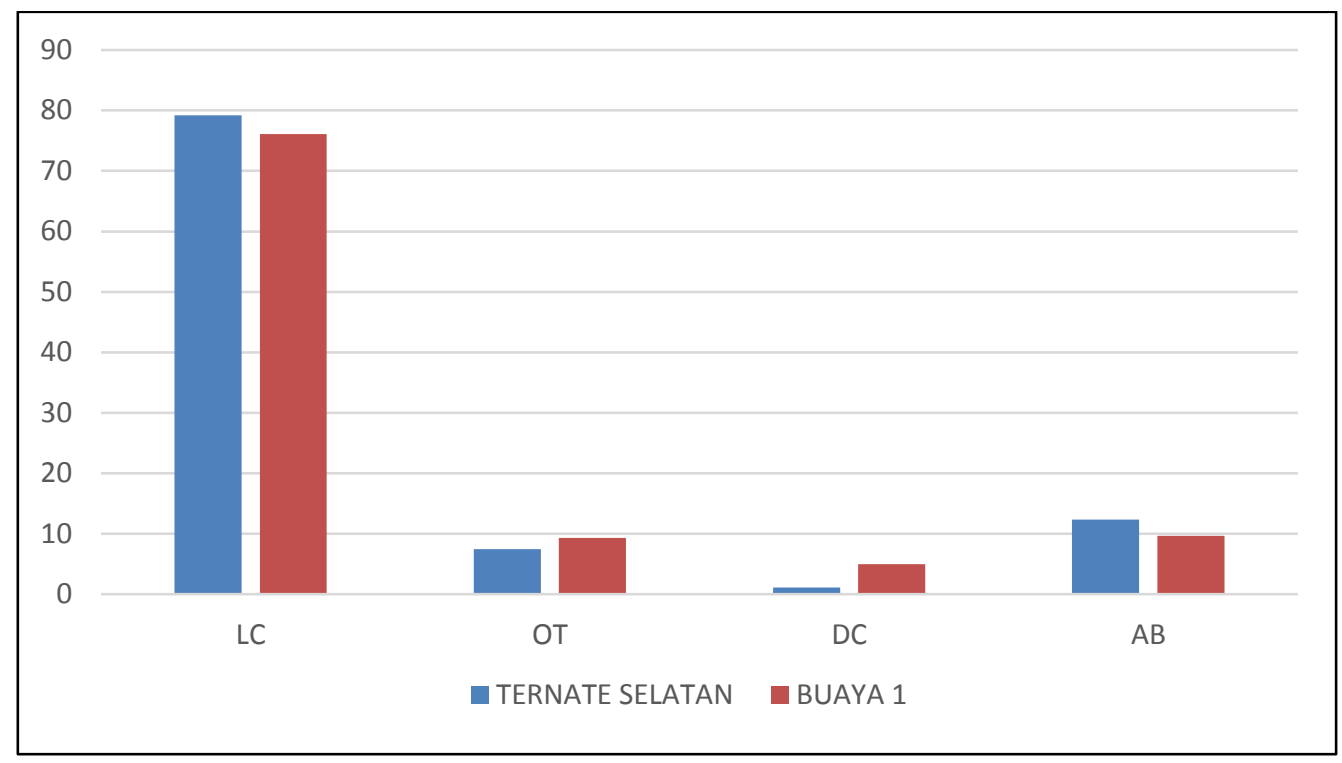

Gambar 4. Presentase dan sebaran terumbu karang kondisi sangat baik

Berdasarkan Gambar 4 tersebut di atas menunjukan bahwa sebaran terumbu karang dengan kondisi sangat baik hanya terdapat di dua stasiun yakni stasiun Ternate Selatan dan Buaya 1 dengan nilai kisaran 
69,26\% - 79,22\%. Tingginya tutupan karang di dua lokasi ini sesuai dengan hasil survey kondisi kesehatan terumbu karang di kawasan SAP Selat Pantar (DKP Kabupaten Alor, 2016) yang menunjukan kondisi karang hidup di lokasi ini presentasenya diatas 60\%. Sementara berdasarkan data survei (WWF, 2015) menyatakan terumbu karang di perairan Ternate Selatan dan Pulau Buaya dengan persen tutupan tertinggi di atas $70 \%$. Nilai persen tutupan terumbu karang yang tinggi itu menegaskan bahwa kondisi karang pada perairan pesisir di ketiga lokasi tersebut termasuk kategori sangat baik (excelent). Sedangkan hasil ini menunjukan nilai tutupan karang sebesar 79,22\% terdapat di kawasan pesisir Ternate Selatan, yang terdiri dari karang bercabang (Acropora) 45\% dan 34,22\% karang keras lainnya (Non Acropora) dengan bentuk pertumbuhan Branching, Foliose dan Mushroom. Salah satu faktor yang menyebabkan kondisi terumbu karang di sekitar kawasan ini masih sangat baik adalah aktifnya pengawasan di sekitar kawasan yang dilakukan oleh pemilik home stay dan masyarakat setempat sehingga membuat lokasi ini aman dari kegiatan penangkapan yang tidak ramah lingkungan.

Penilaian suatu kondisi atau kesehatan dari ekosistem terumbu karang tidak hanya berpatokan pada persentase tutupan karang, karena dapat terjadi dua daerah memiliki persentase tutupan karang hidupnya sama namun mempunyai tingkat kerusakan yang berbeda. Tingkat kerusakan ini terkait dengan besarnya perubahan karang hidup menjadi karang mati. Pengukuran tingkat kerusakan terumbu karang diperoleh melalui pendekatan indeks kematian karang. Nilai indeks kematian karang pada tiap stasiun dapat dilihat pada Gambar 5.

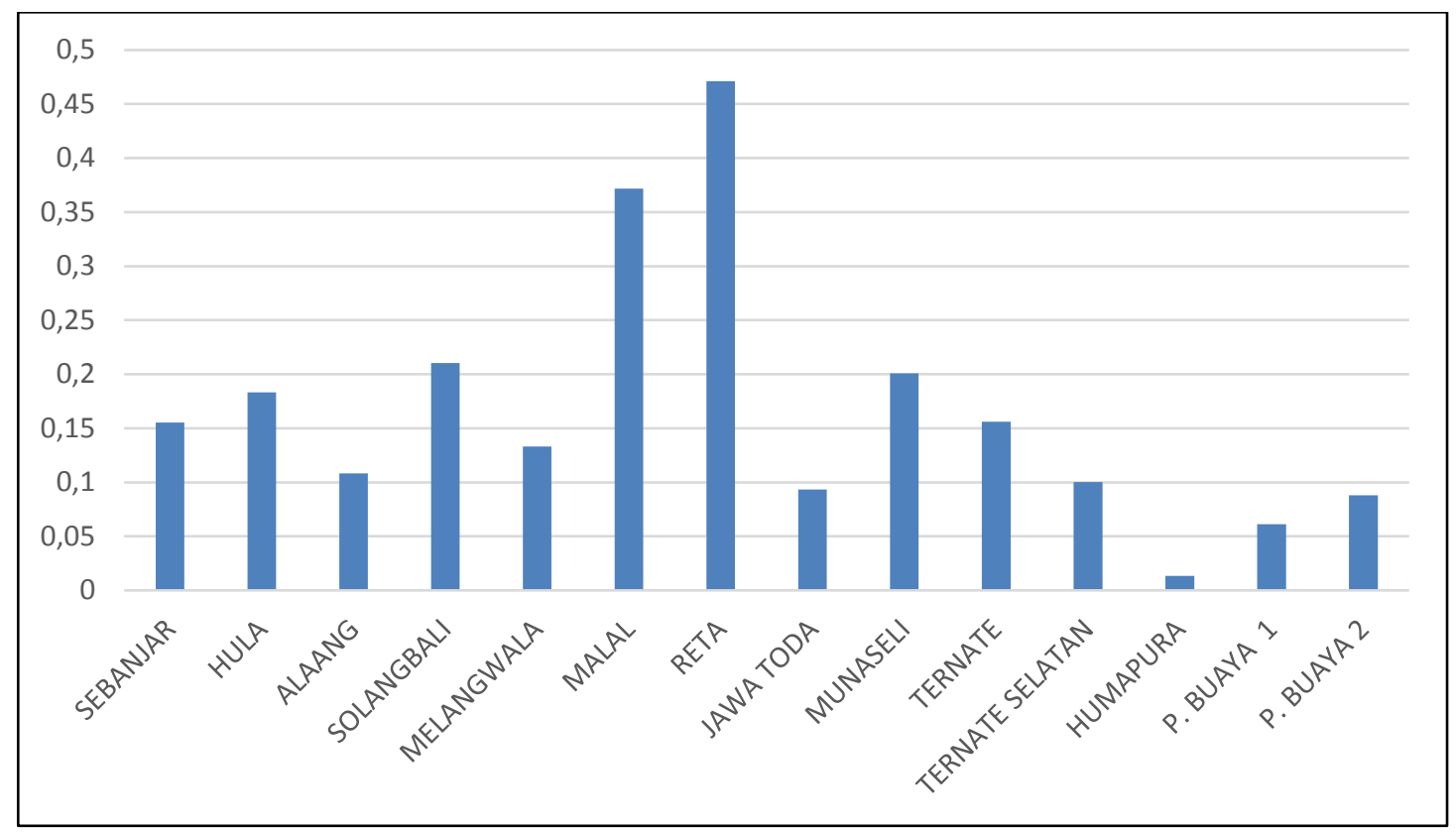

Gambar 5. Nilai indeks kematian karang di tiap stasiun

Gambar 5 di atas menunjukkan nilai indeks kematian karang berkisar 0,01-0,47, dimana nilai tertinggi berada pada stasiun Reta, sedangkan terendah pada stasiun Humapura. Secara keseluruhan nilai indeks kematian karang menunjukkan nilai indeks kematian yang cukup rendah yakni 0,16, menunjukkan perubahan kondisi dari karang hidup menjadi karang mati belum terlalu berarti, hal ini sesuai dengan pernyataan English, et al. (1997), yang menyatakan nilai indeks kematian yang mendekati nol menunjukkan bahwa tidak ada perubahan yang berarti bagi karang hidup, sedangkan nilai yang mendekati satu menunjukkan bahwa terjadi perubahan yang berarti dari karang hidup menjadi karang mati.

\section{KESIMPULAN}

Berdasarkan hasil penelitian dapat disimpulkan bahwa kondisi terumbu karang di perairan Suaka Alam Perairan Selat Pantar, Kabupaten Alor menunjukkan nilai persentase tutupan karang hidup berada pada nilai 
kisaran 27,71 - 79,22\%, nilai tersebut menunjukan tutupan karang berada dalam kategori sedang hingga sangat baik, namun secara keseluruhan nilai persentase tutupan karang hidup sebesar 58,42\% yang tergolong dalam kondisi baik. Sedangkan nilai indeks kematian karang berkisar $0,01-0,47$, namun rata-rata keseluruhan nilai indeks kematian karang sebesar 0,16, menunjukkan perubahan kondisi dari karang hidup menjadi karang mati belum terlalu berarti. Akan tetapi kawasan ini tetap perlu dijaga dari tindakan pemanfaatan yang tidak bertanggung jawab dan merusak agar kondisi terumbu karang tetap terjaga dan dapat lebih baik.

\section{DAFTAR PUSTAKA}

[DKP] Dinas Perikanan dan Kelautan Kabupaten Alor. 2013. Rencana Pengelolaan Kawasan Konservasi Perairan Daerah (KKPD) Kabupaten Alor 314. Kalabahi (ID) : DKP.

[KKP] Kementrian Kelautan dan Perikanan. 2015. Kepmen KP Nomor 35/KEPMEN-KP/2015 Tentang Kawasan Konservasi Perairan Selat Pantar dan Laut Sekitarnya di Kabupaten Alor Propinsi Nusa Tenggara Timur. Jakarta (ID): KKP.

English S, Wilkinson C, Baker. 1997. Survey manual for tropical marine resources. Australian Institute of Marine Science. Townsville. 3(4):89-92.

Fandeli C. 2000. Pengertian dan Konsep Dasar Ekowisata. Yogyakartta (ID): Universitas Gadjah Mada.

Gomez ED. Yap HT. 1988. Monitoring Reef Condition. In : Kenchington, R.A and B. E.T. Hudson (eds). H.187196.

Hartoni, Ario Damar, Yusli Wardiatno. 2012. Kondisi Terumbu Karang di Perairan Pulau Tegal dan Sidodadi Kecamatan Padang Cermin Kabupaten Pesawaran Provinsi Lampung. (ID) Maspari Journal, 2012, 4(1), 46-57.

Suharsono. 1996. Jenis-jenis Karang yang Umum Dijumpai di Indonesia. P3OLIPI Jakarta.

Suharsono, 2008. Jenis-Jenis Karang Di Indonesia. LIPI. Jakarta. iv+372 hlm.

Sukmara, A., Siahainenia, A.J., Rotinsulu, R. 2001. Panduan Pemantauan terumbu Karang Berbasis Masyarakat Dengan Metoda Manta Tow. Proyek Pesisir CRMP Indonesia.

Supriharyono. 2000. Pengelolaan Ekosistem Terumbu Karang. Penerbit Djambatan, Jakarta.

Wilson J. R. \& Green A. 2009. Metode Pemantauan Biologi untuk Menilai Kesehatan Terumbu Karang dan Efektifitas Pengelolaan Kawasan Konservasi Laut di Indonesia (terjemahan). Versi 1.0. Laporan TNC Indonesia Marine Program No 1/09. 46 hal.

Yulianda, F. 2007. Ekowisata Bahari Sebagai Alternatif Pemanfaatan Sumberdaya Pesisir Berbasis Konservasi. Seminar Sains Departemen Manajemen Sumberdaya Perairan. Fakultas Perikanan dan Ilmu Kelautan. Institut Pertanian Bogor. Bogor. 